\title{
Organocatalytic Total Syntheses of (+)- and (-)-Trigonoliimine A
}

\section{Key words}

Michael addition

cinchona alkaloid

trigonoliimine A<smiles>C=C[C+]=CO[Se]c1ccccc1</smiles><smiles>CC(=O)C(C#N)(CC[SeH]Oc1ccccc1)c1ccccc1</smiles>

$96 \%$ yield er $=97: 3$<smiles>CC(=O)C(C#N)(CC[SeH]Oc1ccccc1)c1cccc(Br)c1</smiles>

$93 \%$ yield er $=90.5: 9.5$

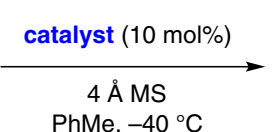<smiles>COC(=O)C([Al])(C#N)CCS(=O)(=O)c1ccccc1</smiles>

14 examples $62-92 \%$ yield er from 87.3:12.7 to $97.9: 2.1$<smiles>COC(=O)C(C#N)(CCCOc1ccccc1)c1ccc(C)cc1</smiles>

$95 \%$ yield er $=97.9: 2.1$<smiles>COc1ccc(C(C#N)(CCCOc2ccccc2)C(C)=O)c([N+](=O)[O-])c1</smiles>

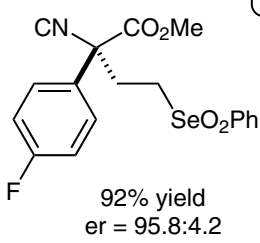<smiles>COC(=O)C(C#N)(CCSc1ccccc1)c1ccccc1[N+](=O)[O-]</smiles>

$90 \%$ yield er $=89.5: 10.5$
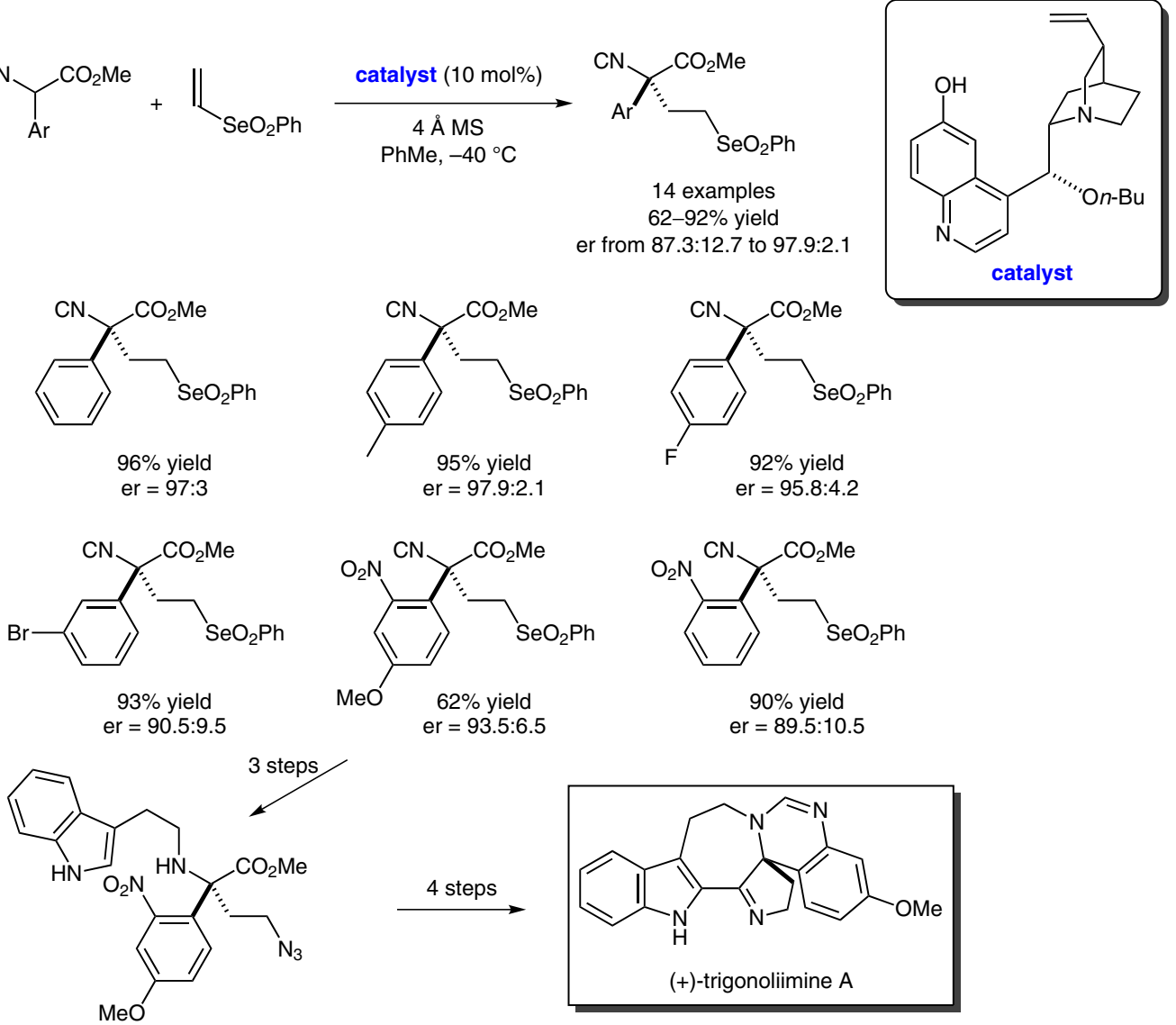

Significance: The Zhu group reports an enantioselective Michael addition of methyl $\alpha$-aryl- $\alpha$-isocyanoacetates to vinyl phenylselenone catalyzed by a cinchona-alkaloid derivative. The obtained enantioenriched $\alpha$-aryl- $\alpha$-(2'-phenylselenonylethyl)- $\alpha$-isocyanoacetates are successfully transformed into linear and cyclic quaternary $\alpha$-amino acids, oxindoles, and pyrrolidinones. A concise total synthesis of $(+)$ and (-)-trigonoliimine $A$ (9 steps, $7.5 \%$ and $6.8 \%$ overall yield) from the shown Michael adduct was completed via a modified Bischler-Napieralski cyclization.

SYNFACTS Contributors: Benjamin List, Philip S. J. Kaib Synfacts 2014, 10(1), 0093 Published online: 13.12.2013 Dol: 10.1055/s-0033-1340402; Reg-No.: B11413SF
Comment: $\alpha$-Isocyanoacetates are well-established glycine templates for the synthesis of racemic $\alpha, \alpha$-disubstituted $\alpha$-amino acids. Yet, the catalytic enantioselective allylation of $\alpha$-isocyanoacetates remains underexploited. The reported Michael addition products are converted further without racemization into the corresponding amines and azides. The absolute configuration of the products obtained from the shown cinchonaalkaloid catalyst was determined after derivatization by $\mathrm{X}$-ray analysis to be $R$. 